\title{
SHAKESPEARE, CARDENIO, AND THE VERTUE MANUSCRIPTS
}

Keywords: early modern English drama, court performances, William Shakespeare, Cardenio, Richard Rawlinson, George Vertue, William Oldys, George Steevens, Edmond Malone, Gerard Langbaine, annotation, marginalia, editing, history of scholarship

While well known to students of the history of art, the eighteenth-century engraver and antiquary George Vertue is rarely mentioned for the incidental but nonetheless important role he played in the history of Shakespearean scholarship. When discussing theatrical performances at the court of James I, editions of Shakespeare from the second half of the eighteenth century frequently feature mysterious references to the manuscripts or papers of the late Mr. Vertue without specifying what these papers contained or what their exact scope might have been. In this paper I chart the history of these manuscripts in order to produce the first complete account of the use to which they were put by Shakespeare scholars as well as to outline the complex manner in which manuscript and print intermingled within the English scholarly community of the eighteenth century. The manuscripts in question are not the extremely valuable notebooks held in the British Library and published in selection by the Walpole Society, ${ }^{1}$ but Vertue's no-

1 For a description of the Vertue collection in the British Library, see Cust and Hind (191314). For the edition of the notebooks, see Vertue (1929-52). 
tebooks are the place where this story properly begins. Special attention is paid to Cardenio, a lost play in which Shakespeare might have had a hand.

An early and influential landmark in the history of English painting, Horace Walpole's Anecdotes of Painting in England was in fact based on the manuscript notes left by Vertue and acquired by Walpole in 1758 (Lewis, 1980, 46). Vertue, claims Walpole, "visited every collection, made catalogues of them, attended sales, copied every paper he could find relative to the art, searched offices, registers of parishes and registers of wills for births and deaths, turned over all our own authors, and translated those of other countries which related to his subject." Fortunately, "he wrote down every thing he heard, saw, or read" (Walpole, 1765-80, vol. 1, vii). However, Walpole complains elsewhere, "all Vertue's memorandums were indigested, and written down successively as he made them in forty volumes, often on loose scraps of paper" (Prior, 1860, 126-27), which makes it hard to find what one is looking for and which suggests that Walpole's skill in constructing a coherent and useful text on the basis of such disconnected material deserves praise (Cust and Hind, 1913-14, 123). An avid collector of facts, Vertue was in touch with a number of antiquarians of his time, indefatigable in his search for information relating to the history of art. He also seems to have recognized the value that some of the material he encountered could have for students laboring in related fields of inquiry. Thus, when Richard Rawlinson, another important antiquary who eventually bequeathed his collection to the Bodleian Library, bought certain manuscripts formerly belonging to Samuel Pepys, Vertue was quick to act.

The valuable library of Samuel Pepys was bequeathed to his nephew, John Jackson, and after his death in 1724 passed to Magdalene College, Cambridge (Latham, 1978). However, a number of manuscripts owned by Pepys were somehow left out of the actual bequest. It is possible that theyprobably as bundles of papers rather than bound volumes-stayed behind in York Buildings, Pepys' home from the 1680s until the end of the century, when he moved to his Clapham residence, to which his library was transported and where Pepys eventually died (Smith and Braybrooke, 1854, vol. 1 , xxix). In any case, they seemed to have traveled around, for Rawlinson rescued them from waste-paper dealers only in 1749, having landed upon them by chance. In a fascinating article entitled "Richard Rawlinson and 
the Chandlers," Brian J. Enright observes that the acquisition of Pepys' papers was one of Rawlinson's final triumphs and that it immediately aroused a great deal of public interest (Enright, 1990, 126-28). Some of the papers were taken by Rawlinson to the Society of Antiquaries, from the minute book of which the following notice survives (dated 13 April 1749):

Dr. Rawlinson showed two MSS. recovered from being made wast paper, formerly part of the collection of Samuel Pepys. There were in the same parcel, above 200 original MSS. relating to the navy, and probably belonging to the public, which falling into ignorant hands have been sold for wast paper, as appear from the covers still remaining. ${ }^{2}$

In addition to Pepys' personal papers and much material concerning naval history, the manuscripts contained the Accounts of the Treasurer of the Chamber, an important source of information on all sorts of royal expenditures, including money spent on theatrical entertainment or on services rendered by individual artists. ${ }^{3}$

Having shown a couple of manuscripts to the Society of Antiquaries, Rawlinson shared the more interesting bits of his find with some of his friends as well. A number of Pepys' manuscripts were apparently loaned to Thomas Carte and, more importantly, to George Vertue, who proceeded to extract from them the information he considered valuable for his own research. ${ }^{4}$ An example of how useful Rawlinson's manuscripts were to Vertue already appears in the first volume of Walpole's Anecdotes, published in the 1760 s, in which the account of Isaac Oliver is enriched by the information about a payment he received for several pictures he drew, recorded "in an office-book of the lord Harrington treasurer of the chambers, in the possession of the late Dr. Rawlinson."

2 Enright (1990, 131), citing BL. Add. MS. 5151, fol. 340 (13 April 1749) and the original minute book of the Society under the same date.

3 For the most recent and the most complete edition of the dramatic records in the Accounts, see Cook and Wilson (1961).

4 See Enright (1990, 128), citing MSS. Rawl. A. 170 (19 May 1749) and A. 464 (for Carte), and MS. Rawl. D. 916 (for Vertue).

5 Walpole $(1765-80$, vol. 1, 166). It can be seen from Vertue's surviving notes that Walpole here draws directly on the extracts from the Chamber Accounts relating, however, to artists 
Whereas Vertue (and Walpole following him) was careful to acknowledge Rawlinson, those that later relied on the information in the Chamber Accounts, as we shall see, were happy to acknowledge only Vertue. Even though theatrical history was not Vertue's primary subject of research, he instantly recognized the value of some of the entries and copied them out, it seems, for the use of his friends. We find the following note by the antiquarian William Oldys dated 27 September 1749 (the year in which Rawlinson acquired Pepys' papers):

Mr. Vertue sent me a transcript of King Charles his Patent to Ben Jonson for 100l. per annum. Also extracts from the accounts of Lord Stanhope, Treasurer of the Chamber to King James, from the Year 1613 to 1616, relating to the payment of the Players for acting of Plays in and between those Years at Court. (Yeowell, 1862, 32)

To illustrate the importance of these accounts for the history of early English drama, it is sufficient to mention that the title of the play Cardenio, acted at court in 1613, is recorded only in these accounts (in the forms Cardenna and Cardenno; cf. Cook and Wilson, 1961, 55-56). Combined with Humphrey Moseley's 1653 entry of a non-extant play entitled The History of Cardenio in the Stationers' Register and Lewis Theobald's Double Falsehood, published in 1728, the 1613 record has inspired scholars to suggest that Theobald's play, obviously based on the Cardenio story from Don Quixote but with the names of the characters changed, bears some relation to the lost (History of) Cardenio. The debate regarding this complicated issue continues to rage, despite the fact that the Arden Shakespeare recently decided to include Double Falsehood among the authentic texts by Shakespeare (helped, in this case, by John Fletcher). ${ }^{6}$

Although Oldys does not mention Cardenio in the memorandum quoted above, it is clear that he had at his disposal the information about this play that would see the light of day only in 1780, when George Steevens, with the help of Isaac Reed, connects the 1613 performance, the 1653 Mo-

and craftsmen rather than to players; cf. Vertue (1929-52, vol. 5, 75-76).

6 The Arden edition provides the basic account of the controversy (Hammond, 2010); for some corrections and reservations, see Lupić (forthcoming). 
seley entry, and the 1728 Theobald play-thus providing the basis for the further study of the Cardenio problem (Lupić). Oldys' importance in the history of studying early English drama is nonetheless huge. His annotated copy of Gerard Langbaine's An Account of the English Dramatic Poets (1691) served generations of eighteenth-century scholars as a goldmine of information that they honored by copying Oldys' marginal notes into their own interleaved copies of Langbaine and then adding results of their own studies or correcting what their predecessors had gotten wrong. ${ }^{7}$ Oldys' manuscripts, however, were dispersed after his death, and the many fascinating references to his "poetical bag," his "parchment budget," his "white vellum pocket-book," or his various unpreserved catalogues-all lost except as fleeting promises in the surviving manuscript material, mostly his annotations in the margins of printed books - must make any student of early English literature a little sad and a little annoyed. ${ }^{8}$ It is in his annotated Langbaine that one sees Oldys actually using the extracts he received from Vertue.

Oldys annotated two copies of Langbaine's Account. The first one, which was acquired by Thomas Coxeter ${ }^{9}$ in the 1720s through a bookseller while Oldys was away from London, served as a source for some information in the five-volume Lives of the Poets of Great Britain and Ireland by Robert Shiells and Theophilus Cibber, who bought Oldys' Langbaine at the auction of Coxeter's books (Watkin-Jones, 1936; Disraeli, 1861, vol. 4, 433-34). The title page of this work announced that the lives were compiled with the help of a variety of books, "and especially from the MS. Notes of the late ingenious Mr. Coxeter and others" (Shiells and Cibber, 1753). Obviously annoyed by the loss of his precious volume, Oldys started annotating his second Langbaine in the 1730s, or perhaps even a little earlier. Unlike the first one, which seems to have perished, ${ }^{10}$ the second one is now held in the British Library (C. 28. g.

7 On the place of Oldys in English literary historiography, see Lipking (1967) and (1970, 6685); on the annotated Langbaines, see Watkin-Jones (1936).

8 A moving account is provided by Disraeli (1861, vol. 4, 425-47).

9 Coxeter was a friend of Theobald's; he supplied him with several old plays, as Theobald acknowledges in a letter to Warburton (November 1731), calling him "my Friend Thomas Coxeter Esq." See Jones (1919, 287); also Theobald (1733, vol. 1, lxvii).

10 I have not been able to find any facts in the 1753 Lives of the Poets of Great Britain and Ireland that would depend on the records of the Accounts of the Chamber, which suggests that Oldys' first annotated Langbaine, from the 1720s, did not contain any information from the 


\section{1), where it ended up after the death of Thomas Birch in 1766 (Watkin-Jones, 1936, 82). Birch bought the copy in question, as Disraeli points out, "at an auction of some of Oldys's books and manuscripts" (1861, vol. 4, 434). Three years before he died, however, Birch loaned it to Thomas Percy, who copied Oldys' notes into an interleaved copy of his own and added further notes.}

Pepys papers (the Lives, however, usually only record the dates of the printed editions of plays if they provide any date at all). This is a point worth mentioning because it is important to know what Theobald, the author of Double Falsehood (1728), might have known about the mention of Cardenio in the court records (and thus whether he was telling the whole truth in the preface to Double Falsehood). Theobald could have gained access to Oldys' first annotated Langbaine through his friend Coxeter, who-as I have explained above-acquired Oldys' copy in the 1720s. However, with Oldys' first Langbaine apparently lost to posterity, one must be content with concluding that Oldys seems to have obtained extracts from the Accounts of the Chamber for the first time through Vertue in 1749. I mention the admittedly slim possibility of Oldys' earlier acquaintance with the Accounts of the Chamber from the Pepys papers only because it was in the 1720 s that these papers make a brief and mysterious appearance in print (cf. Latham, 1983, 90). In the anonymously published Memoirs of the English Affairs, Chiefly Naval, from the Year 1660, to 1673 (1729), based on the letters of King James II, the compiler refers to "these invaluable Originals" for which every reader is indebted "to the deserving Memory of the Lord Frederick HowARD" (xx). In a brief conclusion to the work, the same person notes that "here endeth that invaluable Manuscript (of his Royal Highness, JAmes Duke of York) a faithful Copy of which is now submitted to public Censure" and promises that "if the Papers meet with a Reception equal to their merit, we shall continue these Naval-Memoirs down to the Revolution, 1688, from the Original Manuscripts of Samuel Pepys, Esq; now in our Possession" (280). There was no continuation; there was not even an identification of the publisher or printer of the volume. Latham speculates that the papers in question may not have been the ones bought by Rawlinson in 1749 , suggesting instead that the latter reached the market after "the Jackson household at Clapham was broken up" around 1747 (1983, 90). This "conjecture," as Latham refers to it, fails to explain what exactly the 1729 publication then drew on and it does not take into account the suggestion made in earlier criticism that the manuscripts stayed behind in York Buildings (Smith and Braybrooke, 1854, vol. 1, xxix). It would perhaps be worth exploring whether any of the Rawlinson manuscripts currently in the Bodleian correspond to the material found in the 1729 publication. Firth $(1913,227)$ notes, however, that "for the period from 1660 to 1688 the papers formerly belonging to Pepys and now among the Rawlinson MSS., are so numerous that the index to them fills seven columns." He also observes that "the letters relating to the second Dutch war, and a good many others, deserve printing"; the same war features frequently in the 1729 publication, not mentioned by Firth. The publication by Smith (1841), which Firth mentions and where some letters relating to naval affairs were printed, contains, as far as I can see, no letters from the Duke of York, only to him.- It thus remains possible that Theobald, even without Coxeter and Oldys, gained access to the Pepys papers, obviously in the possession of a London bookseller in the late 1720s, a period during which Theobald was engaged in intensive study of early English drama, especially Shakespeare. 
Percy in turn loaned his newly annotated Langbaine to Thomas Warton in 1769 and to George Steevens in the early 1770s. Edmond Malone compiled his interleaved Langbaine on the basis of Steevens' copy, loaned to him in 1777 (Watkin-Jones, 1936, 82-83). He expressly noted (Bodleian Library Mal. 129, fol. 30r): " $\mathrm{M}^{\mathrm{r}}$ Steevens the last \& best editor of Shakespeare made a transcript from $\mathrm{D}^{\mathrm{r}}$ Percy's copy; and from his transcript this is made." In all of these, the notes of different contributors are identified by different letters, such as $\mathrm{O}$ for Oldys, $\mathrm{S}$ for Steevens, and so on. ${ }^{11}$

The surviving copy of Oldys' Langbaine, however, does not contain any longer extracts, only notes crowded in the margins of the original volume (unlike the interleaved copies of his successors). Here one does find information that clearly comes from the Vertue extracts. On page 207 of the Account, for example, where Langbaine could say for The Captain only that it was a comedy by Beaumont and Fletcher, Oldys notes that it was "acted at Court 20 May 1613 by the Kings Comp. under Jn ${ }^{\circ}$ Hemmings \&c." ${ }^{12}$ However, there is no mention of either Cardenno or Cardenna in Oldys' notes, an indication that he used the extracts received from Vertue selectively. His Langbaine was therefore not the source for the information about the 1613 performance of Cardenio published in the 1780 Supplement to the 1778 Johnson-Steevens edition of Shakespeare's plays (Malone, 1780, vol. 2, 717-19).

Oldys, in other words, does not seem to be the only person to whom Vertue sent the extracts from the court accounts. It is, in fact, possible to establish that David Garrick, the famous eighteenth-century actor who collected old English plays, obtained the same or comparable material either from Vertue or through an intermediary, and that this material was then copied by George Steevens into his four-volume Langbaine, probably in

11 I have personally inspected only two sets: that owned by Steevens, now in the British Library (in 2008), and that owned by Malone, now in the Bodleian (in 2006). However, at that time I was looking for something else and was not paying special attention to the problem I am discussing here. All of the copy-specific details (and therefore the presence of the Cardenno and Cardenna entries) for both Oldys' and Steevens' Langbaine I owe to the kindness of András Kiséry, who, while in the British Library, took the time to look at the copies in question and answer specific queries.

12 Oldys' note is quoted by Dyce (1843, vol. 3,219$)$. 
the early 1770s. Steevens' copy (British Library MSS Add. 22592-22595) reproduces Oldys' marginal annotations, such as the note on The Captain instanced above, ${ }^{13}$ but it also has the extracts provided by Vertue. In the fourth volume of Steevens' Langbaine there are five additional leaves inserted between the last two pages of the Shakespeare entry in the Account (pp. 468-69). It is there that one finds an "Account from Old plays \& Players from Mr. George Vertue's Mss" and is informed that "in the Accounts of Ld. Harrington Treas. of the Chambers to James Ist in his Receipts and payments from the tenth to the eleventh of that King, appear these following." Among the entries that follow are Cardema and Cardano, as Vertue seems to have deciphered the titles.

The repeated references to the "Vertue MSS," as they came to be called in the eighteenth century by the editors of Shakespeare, produced a lot of confusion among those that had no access to them, mostly because those that had the extracts did not bother to either publish them in full or to disclose exactly where they came from. Steevens did leave a note in his Langbaine, following the extracts, which said that "the Books from which these notes were taken, with several others now lost, belonged to Secretary Pepys, and afterwards to Dr. Rawlinson, who lent them to Mr. Vertue." However, it took more than thirty years for the complete account of the extracts (without, still, the extracts themselves) to be made public. In his Supplemental Apology for the Believers in the Shakspeare-Papers, published in 1799, George Chalmers argued that Othello, "this great work, of an uncommon maker," must "on account of its excellence" be among Shakespeare's last creations, and that it therefore should be placed in the year 1614 (Chalmers, 1799, 457). The problem was that his venerable Shakespearean predecessorsespecially Malone, at whom this treatise is directed-noted that Othello was performed at court in 1613, vaguely referring to a manuscript of Vertue as their authority. Chalmers was unrelenting. "I would bow to any register of the time," he exclaims, "but, I will not allow Vertue, though a very diligent collector, to draw deductions for me, which are to militate against the strongest probabilities" (1799, 462-63).

13 The note, ascribed to Oldys, can be found on folio 59v, facing page 207 of the Account, in the second volume of Steevens' copy. 
To this statement, however, he appends a footnote that, unwittingly, supplies that crucial piece of information that links Vertue to the Shakespeare editors and that otherwise would have been lost. The footnote says that Chalmers made some inquires "what manuscript of Vertue's it were, which I saw so often quoted about scenic matters," and was, through the assistance of a friend, furnished with a reply from Steevens. The reply basically repeats what is found in Steevens' Langbaine, explaining further that "there is a MS. note, subjoined to the MSS. of Vertue" which traces the history of the Vertue extracts from Pepys through Rawlinson. Steevens' reply, however, also adds that the Vertue manuscripts "about thirty years ago, were lent to Mr. Steevens by Mr. Garrick" (Chalmers, 1799, 463). The statement accords with the fact that Steevens was annotating his Langbaine in the early 1770s and that he was at the same time actively corresponding with Garrick, whose collection of old plays furnished Steevens with a number of new facts and illustrative details for the 1773 edition of Shakespeare. ${ }^{14}$

Although there is no reason to doubt Steevens' statement-which only survives thanks to Chalmers, who received it through a friend-one other possibility is worth exploring. The erudite modern biographers of Garrick never mention Vertue in connection with Garrick ${ }^{15}$ and Vertue's own manuscript notes from 1746 suggest that, at that time at least, Garrick was not among his acquaintances. ${ }^{16}$ Vertue died in 1756 , seven years after Rawlinson acquired the Pepys papers, and so if there was any communication between Vertue and Garrick it had to take place during that period. In the 1740s Garrick was already establishing himself as a significant collector of books,

14 See especially Steevens' letter to Garrick dated 3 December 1772 (Boaden, 1831-32, vol. 1, 500-02), in which he sends Garrick the draft of his Advertisement to the 1773 edition and invites him to introduce what changes he pleases. Unlike Johnson in 1765, Steevens decided to mention Garrick in a positive light: "I have taken the liberty to introduce your name, because I have found no reason to say that the possessors of the old quartos were not sufficiently communicative. You will remember the circumstance to which I allude."

15 Stone and Kahrl (1979). Vertue is not mentioned in the index to Garrick's letters either; cf. Little and Kahrl (1963). There is some uncertainty as to when exactly the Garrick Collection was formed. It is likely that he also bought books at the sale of Theobald's library in 1744; cf. Kahrl and Anderson $(1982,4,16)$.

16 The only relevant note reads: "the end of June came out a Print of K. Richd 3 in the Character of Garrick the present famous player or Comedian. whose performances are much admired-by all persons-His picture is painted by Hogarth"; Vertue (1929-52, vol. 3, 130). 
having purchased both the old plays that Robert Dodsley used in order to publish his collection and the plays from the famous Harleian Library, which went on sale in $1744 .{ }^{17}$ It is also known that in both of these undertakings he was probably helped by William Oldys, one of the cataloguers of the Harleian Library prior to its sale (the other was Samuel Johnson). ${ }^{18}$ This leaves two possible explanations for the manner in which the extracts in question reached Garrick. First, that Vertue thought Garrick-the collector of old plays-should have such information, and therefore sent it to him (thus initiating an acquaintance for which there seems to be no other proof); second, that Oldys, who was helping Garrick in his collecting endeavors, thought that the extracts he received could have no better home than Garrick's library of old plays. Oldys may have simply picked what suited him for the correction and supplementation of his Langbaine, and sent the extracts on to Garrick. Vertue was unlikely to extract information devoted exclusively to plays and players (the information that in the same accounts related to the history of art Vertue extracted separately) ${ }^{19}$ unless he had a specific recipient in mind who might be interested in this sort of information, and there is proof that Oldys was such a recipient. Without Steevens, however, who fortunately made a copy for himself, the information relating to Cardenio - among other things - and preserved in these valuable extracts would have been lost to the rest of the century. ${ }^{20}$

17 Stone and Kahrl $(1979,169-70)$. The Dodsley plays derived from the Harleian Library too and seem, again, to have been obtained by Dodsley through Oldys.

18 I am slightly confused by the biographers' statement (Stone and Kahrl, 1979, 169) that Garrick purchased the plays "by the counsel of Oldys," which is followed by this: "If Garrick did not meet Oldys, the most learned literary antiquarian when he was the librarian (and later with Johnson the cataloguer) of the Harleian Library, Garrick later supported Oldys's scholarship and made purchases from his library" (170). In any case, it seems clear that some sort of connection was in place.

19 See above, note 5 .

20 The theory that Vertue's extracts traveled, in their original form, from Oldys to Garrick may find some support even in the note provided by Chalmers. Steevens there says that "there is a MS. note, subjoined to the MSS. of Vertue," which identifies their provenance. This sounds as though Steevens himself had seen the Vertue originals, which would have to mean that they stayed with Garrick. It is equally possible that the provenance note was simply copied with the extracts and that one should therefore not read too much into Chalmers' report, obtained, as we have seen, through an intermediary. 
The information would have been lost unless, that is, someone decided to consult the Rawlinson manuscripts themselves, which, as has been noted, arrived in the Bodleian in 1756. The conclusion of Chalmers' footnote suggests otherwise. "Much is to be lamented," he records, "that any MS. or book, which furnished an illustration of Shakspeare, and having once been seen, should ever disappear" (Chalmers, 1799, 463). The original Vertue extracts may have disappeared by that time, but the Rawlinson manuscripts from which they were made were safely deposited in the Bodleian-yet no Shakespeare editor from the eighteenth century seems to have consulted them for this purpose. Whenever the court performances of plays possibly related to Shakespeare or his company from the second decade of the seventeenth century are mentioned in the Shakespeare editions, the source is the mysterious Vertue MS. The earliest reference I have unearthed is to be found in the Johnson-Steevens edition of 1773, in which in a concluding note on Much Ado About Nothing Steevens observes: “This play (as I understand from one of Mr. Vertue's MSS.) formerly passed under the title of Benedict and Beatrix," ${ }^{21}$ which is indeed the title under which the play appears, in the same entry as Cardenno. Malone's mention of Cardenio in his essay on the chronological order of Shakespeare's plays, published in the 1778 Johnson-Steevens edition, is clearly indebted to the same source even though Malone provides no reference. ${ }^{22}$

Malone does, however, frequently cite "the Ms. of the late Mr. Vertue" and refers to "the papers of the late Mr. George Vertue" or "the Mss. of Mr. Vertue." 23 These references persist into his 1790 edition (Malone, 1790, vol.

21 Johnson and Steevens (1773, vol. 2, 337). Steevens goes on to say that the six plays for which Heminges received forty pounds were performed at Hampton-Court, which is not specified either in the Rawlinson manuscript or in the Vertue extracts as preserved in Steevens' Langbaine. By referring to the six plays Steevens thus referred to Cardenio as well without, however, specifically naming it.

22 Johnson and Steevens $(1778$, vol. 1, 331). Cardenio is listed among the plays for which only titles survive. The History of Cardenio is not listed because the information from the Stationers' Register became available only when Steevens transcribed the relevant entries in the 1780 Supplement (Malone, 1780, vol. 2, 717-19), having gone over the Register again (the results of his first inspection were reported in Johnson and Steevens, 1778, vol. 1, 253-68).

23 Johnson and Steevens (1778, vol. 1, 285), in connection with The Winter's Tale; p. 336, in connection with Caesar's Tragedy; p. 343, in connection with The Tempest. See also the mention of "the MS. Register of lord Stanhope, treasurer of the chambers to king James I." (Ma- 
1 , part $1,348,378$ ) and can be found as late as the 1821 twenty-one-volume Shakespeare prepared from Malone's papers by James Boswell (1821, vol. 2, 403, 450-51, 466). It is therefore wrong to assume, as scholars do, that Malone actually consulted the relevant Rawlinson manuscript when he wrote about the problem of lost plays in $1778 .{ }^{24}$ Malone started consulting manuscripts in the Oxford libraries only in the early 1790s (Martin, 1995, 173). His major source of information about the materials deposited in the Bodleian Library was in the meantime Thomas Warton, with whom he commenced active correspondence in 1781, a year after the Supplement to the 1778 Johnson-Steevens edition of Shakespeare was published and three years after Malone's mention of Cardenio in the list of lost plays. ${ }^{25}$

The relevant Rawlinson manuscript was in fact so rarely consulted that even in the middle of the nineteenth century, when the entries about the court performances in 1613 were first published as a group, the information was taken from the Vertue extracts. In order to understand the problem,

lone, 1780 , vol. 1, 25) as well as "the payments made in 1613 by lord Stanhope, treasurer of the chambers to king James I. on account of plays performed at court in that year" (Malone, 1780, vol. 1, 52).

24 Freehafer $(1970,160)$ writes: "Malone's list of 1778 includes ten plays that have been associated with Warburton, but his listing of 'The Nobleman, by Cyril Tourneur' must be disregarded, because Malone derived it from a schedule of plays 'acted in the year 1613,' which he found in a copy of Lord Stanhope's accounts in Bodleian MS Rawlinson A239." Freehafer argues $(1970,159)$ that Malone knew of the John Warburton list of plays (BL MS. Lansdowne 807) when he compiled his own list of plays that may still survive in manuscript. As Lancashire has shown, however, Malone learned about the list much later, through Steevens, who anonymously published it in The St. James's Chronicle in 1780. Lancashire (1974) then demonstrates that Malone in fact drew on his annotated Langbaine, which, as has been seen, he transcribed from Steevens' copy. This helps to explain, as Lancashire rightly points out $(1974,244)$, where Malone obtained information about Tourneur's authorship of The Nobleman; namely, in Oldys' notes on Langbaine. She, however, seems to concur with Freehafer that Malone consulted MS. Rawl. A. 239 for the information on the court performance $(1974,244)$. Because The Nobleman is included in the Vertue extracts (where the year is specified), there is no need to assume Malone's direct acquaintance with the Rawlinson manuscript.

25 Fairer $(1995,435)$. The first record of Malone's visit to Oxford-not to consult manuscripts but to see the picture gallery there-dates from 1784; see Osborn $(1970,324)$. There is, however, a note in the 1780 Supplement about Shakespeare and Davenant that was sent to Malone by "the learned author of The History of English Poetry" (Malone, 1780, vol. 1, 69-70). I have not been able to ascertain where Malone obtained the detailed description of Kemp's Nine Daies Wonder (1600), kept in the Bodleian (cf. Malone, 1780, vol. 2, 681). 
one should remember that the Accounts of the Treasurer of the Chamber existed in several different versions. ${ }^{26}$ This is where the special value of the Rawlinson manuscripts (and, consequently, the Vertue extracts) lies because the versions of the entries they preserve are much more detailed than those found in other surviving copies of the same accounts. So when Peter Cunningham published his Extracts from the Accounts of the Revels at Court in 1842 , he transcribed the entries he found "wholly new to our dramatic history" from the Accounts of the Treasurer of the Chamber-among them those corresponding to the records of payments made on 20 May and 9 July 1613 in which Cardenno and Cardenna are mentioned-but his Somerset House documents contained no information about the titles of plays, only about the money expended and the number of plays performed. ${ }^{27}$ When three years later Cunningham came across Joseph Haslewood's annotated Langbaine - which had Steevens' copy as its basis ${ }^{28}$ - he noticed the Vertue

26 For the full explanation, see Cook and Wilson (1961, xvii-xviii); also Chambers (1923, vol. 4, 134-35). I hope to have shown that Chambers is incorrect in claiming that extracts from the Rawlinson manuscript were taken "by Vertue and Oldys." His account of the later fate of the extracts is likewise erroneous: "These had passed, in the case of the Oldys notes through Percy, to Steevens, and from him to Hazlewood [sic]." I have established above that the Vertue extracts are not to be found in Oldys' Langbaine, which also accounts for their absence from Percy's copy, annotated on the basis of Oldys'. I am grateful to Joseph Marshall, who, upon my sudden request, kindly checked Percy's Langbaine, held in the Edinburgh University Library, shelfmark La.647.

27 Cunningham, 1842, xxxiv, xliii. Cunningham used his appointment in the Audit Office, Somerset House, to look for information regarding literary history, as he explains (1842, vii).

28 There is some confusion about the history of Haslewood's copy. Watkin-Jones $(1936,84)$ says that Haslewood's copy followed Steevens' and that many notes in Haslewood's copy credit Steevens even when it is found that Percy had contributed the same notes to his copy (which Steevens used). Watkin-Jones does not, however, mention the remarks in Yeowell's account of Oldys according to which "it was from Bishop Percy's copy that Mr. Joseph Haslewood annotated his Langbaine" (Yeowell, 1862, xliii). Yeowell proceeds to quote Haslewood (from an unidentified source) intimating as much; his account was accepted into the DNB and as such has persisted to our day (s.v. Oldys). Elton (1904, 444-45) I think erroneously claimed that Cunningham's statement was incorrect and that the source of the extracts was Reed's copy, which contained Steevens' notes; cf. also Watkin-Jones, "Langbaine's Account," 83). On the other hand, Elton repeated Haslewood's claim that Percy had been his source $(1904,448)$, specifying that the statement is recorded early in Haslewood's Langbaine. This mess can be cleared up only by the inspection of all the volumes in question, which I have not been able to undertake. It is possible that Haslewood had access to both Steevens' and Percy's copies. One thing Elton did manage to clear up is the confusion about "Lord Harrington, Treasurer of the Chamber," who features in the Vertue extracts. Elton observes $(1904,436-37)$ that 
extracts and realized that they provided information his own Revels volume did not. He proceeded to print them, noting that "both Steevens and Malone refer occasionally to these Notes under the general name of Mr. Vertue's MSS" and insisting that "the Notes themselves and the history of the source from whence they were derived are here printed and pointed out for the first time" (Cunningham, 1845, 126). He was as unaware of the note in Chalmers-which linked Vertue and Steevens through the figure of Garrick-as he seems to have been of the fact that much more was to be found in the Rawlinson manuscripts in the Bodleian Library.

It took almost an entire century after Vertue for another extract to be again taken directly from the Rawlinson manuscript. In 1848, James Orchard Halliwell printed only one entry from the relevant Rawlinson manuscript (A. 239) in his Life of William Shakespeare (Halliwell, 1848, 272). The entry dated 20 May 1613 features several plays by Shakespeare (such as Much Ado About Nothing, The Tempest, and The Winter's Tale), but not Cardenio. Because Halliwell was interested only in Shakespeare's plays and because the two entries mentioning Cardenio fail to specify the play's author(s), he did not include them in his selection. He was, it can be speculated further, obviously disinclined to identify Moseley's 1653 entry of The History of Cardenio in the Stationers' Register (ascribed there to Fletcher and Shakespeare) with Cardenna and Cardenno of 1613, or to give much authority to Moseley's list. ${ }^{29}$ After Halliwell, the relevant entries-this time

one should read Lord Stanhope of Harrington, who was indeed the treasurer, and not Lord Harington (of Exton; the spelling, however, suggested the difference). He did not realize that this was already noticed by the Shakespeare editors; cf. Malone's correction of himself in the 1780 Supplement: "For lord Harrington, read lord Stanhope" (Malone, 1780, vol. 1, 77; he had obviously been misled by the Vertue abstracts [cf. Johnson and Steevens, 1778, vol. 1, 313] - the mistake, however, persists into the 1821 edition: Boswell, 1821, vol. 2, 398). Elton's treatment of the Vertue MSS, though disconnected, is very helpful, but I hope I have produced a more coherent and altogether a more accurate account.

29 Cf. Halliwell's later description of Cardenio, in which the link between that title and The History of Cardenio is still qualified by "perhaps" (Halliwell, 1860, 429): "CARDENIO. A play so called was acted more than once at Court in the year 1613. It is perhaps the same play which was entered on the registers of the Stationers' Company, in 1653, as the History of Cardenio." In the 1848 publication, Halliwell states that the Rawlinson manuscript "has been referred to by Malone," but provides no proof. All I can find is a note in the 1821 edition of Shakespeare (Boswell, 1821, vol. 2, 429, not found in Malone, 1790) in which a 1612 payment to a picture maker is mentioned and reference is made to "MS. Stanhope in bib. Bodl." This confusing 
including Cardenio-were published in The New Shakspere Society's Transactions for 1875-76 (pp. 419-20), directly from the MS. Rawl. A. 239, with the correct reading of the titles: Cardenna and Cardenno. That late date is the point where the story of Mr. Vertue's manuscripts finally ends.

This paper has done several things. First, it has traced the history of the extracts from the Accounts of the Treasurer of the Chamber that George Vertue made soon after Richard Rawlinson obtained the relevant manuscripts and which he shared with his antiquarian friend William Oldys. These extracts played a minor but important role in the history of eighteenth-century Shakespearean scholarship. Second, it has reasserted the importance of studying the surviving manuscript evidence from the eighteenth century, especially when it appears in the margins of books (as in the case of Oldys' Langbaine) or on the leaves inserted inside the printed book (as in the case of Steevens). Finally, by following the history of the Vertue extracts, the paper has shed additional light on the problem of Cardenio, a non-extant play that is sometimes ascribed to Shakespeare. It is only through the study of the specific uses of the Vertue extracts in the second half of the eighteenth century that it can be fully understood how Cardenio came to feature as a Shakespearean problem.

\section{REFERENCES}

Boaden, James, ed. The Private Correspondence of David Garrick with the Most Celebrated Persons of His Time. 2 vols. London: Colburn and Bentley, 1831-1832.

Boswell, James, ed. The Plays and Poems of William Shakspeare. 21 vols. London: F. C. and J. Rivington etc., 1821.

reference (surely it was MS. Rawl.) may have been due to Boswell, who on p. 464 of the same volume verifies the 1613 performance of The Winter's Tale by referring to "MS. of the late Mr. Malone" (Malone, 1790, vol. 1, part 1, 348, had, rightly, "Ms. of the late Mr. Vertue"). Very early in their correspondence (22 June 1781), Warton draws Malone's attention to a Rawlinson manuscript (Rawl. Poet. 160, containing the poem "Shall I die?"), but there is no mention of the court accounts in the letters that ensued; see Fairer (1995, 439-40). 
Chalmers, George. A Supplemental Apology for the Believers in the Shakspeare-Papers. London: Thomas Egerton, 1799.

Chambers, Edmund Kerchever. The Elizabethan Stage. 4 vols. Oxford: Clarendon Press, 1923.

Cook, David, and F. P. Wilson, eds. Dramatic Records in the Declared Accounts of the Treasurer of the Chamber, 1558-1642. (= Malone Society Collections 6). Oxford: Malone Society Reprints, 1962.

Cunningham, Peter. Extracts from the Accounts of the Revels at Court. London: The Shakespeare Society, 1842.

Cunningham, Peter. "Plays Acted at Court, Anno 1613." Shakespeare Society's Papers 2 (1845): 123-26.

Cust, Lionel and Arthur M Hind. "George Vertue's Note-Books and Manuscripts Relating to the History of Art in England." Annual Volume of the Walpole Society 3 (1913-14): 121-39.

Disraeli, Isaac. Curiosities of Literature. 4 vols. Boston: Crosby, Nichols, Lee and Company, 1861.

Dyce, Alexander, ed. The Works of Beaumont \& Fletcher. 11 vols. London: Edward Moxon, 1843.

Elton, Charles Isaac. William Shakespeare: His Family and Friends. New York: E. P. Dutton \& Company, 1904.

Enright, B. J. "Richard Rawlinson and the Chandlers." Richard Rawlinson: A Terentenary Memorial. Ed. Georgian R. Tashjian, David R. Tashjian, and Brian J. Enright. Kalamazoo: Western Michigan University, 1990: 121-32.

Fairer, David, ed. The Correspondence of Thomas Warton. Athens: U of Georgia P, 1995.

Firth, Charles H. "Papers Relating to the Navy in the Bodleian Library." The Mariner's Mirror 3.8 (1913): 225-29.

Freehafer, John. "John Warburton's Lost Plays." Studies in Bibliography 23 (1970): 154-64.

Halliwell, James Orchard. The Life of William Shakespeare. London: John Russell Smith, 1848.

Halliwell, James Orchard. A Dictionary of Old English Plays. London: John Russell Smith, 1860. 
Hammond, Brean, ed. Double Falsehood. London: Arden Shakespeare, 2010.

Johnson, Samuel, and George Steevens, eds. The Plays of William Shakespeare, 1st ed. 10 vols. London: C. Bathurst etc., 1773.

Johnson, Samuel, and George Steevens, eds. The Plays of William Shakspeare, 2 nd ed. 10 vols. London: C. Bathurst etc., 1778.

Jones, Richard Foster. Lewis Theobald: His Contribution to English Scholarship, with Some Unpublished Letters. New York: Columbia UP, 1919.

Kahrl, George Morrow, and Dorothy Anderson. The Garrick Collection of Old English Plays: A Catalogue with an Historical Introduction. London: The British Library, 1982.

Lancashire, Anne. "Warburton's List and Edmond Malone: A Non-Existent Relationship." Studies in Bibliography 27 (1974): 240-48.

Latham, Robert, ed. Catalogue of the Pepys Library at Magdalene College Cambridge. Vol. 1. Cambridge: D. S. Brewer, 1978.

Latham, Robert, ed. The Diary of Samuel Pepys. Vol. 10: Companion. Berkeley: U of California P, 1983.

Lewis, Wilmarth S. "Horace Walpole, Collector." Proceedings of the Massachusetts Historical Society, 3rd ser. 92 (1980): 45-51.

Lipking, Lawrence. "The Curiosity of William Oldys: An Approach to the Development of English Literary History." Philological Quarterly 46 (1967): 385-407.

Lipking, Lawrence. The Ordering of the Arts in Eighteenth-Century England. Princeton: Princeton UP, 1970.

Little, David M., and George M. Kahrl, eds. The Letters of David Garrick. 3 vols. Cambridge, MA: Harvard UP, 1963.

Lupić, Ivan. "Malone's Double Falsehood." The Quest for Shakespeare's Cardenio. Ed. David Carnegie and Gary Taylor. Oxford: Oxford UP, forthcoming.

Malone, Edmond, ed. Supplement to the Edition of Shakspeare's Plays Published in 1778 by Samuel Johnson and George Steevens. 2 vols. London: C. Bathurst etc., 1780.

Malone, Edmond, ed. The Plays and Poems of William Shakspeare. 10 vols. London: H. Baldwin, 1790. 
Martin, Peter. Edmond Malone, Shakespearean Scholar: A Literary Biography. Cambridge: Cambridge UP, 1995.

Osborn, James M. "Edmond Malone and Oxford." Eighteenth-Century Studies in Honor of Donald F. Hyde. Ed. William H. Bond. New York: Grolier, 1970: 323-38.

Prior, James. Life of Edmond Malone, Editor of Shakespeare. London: Smith, Elder \& Co., 1860.

Shiells, Robert, and Theophilus Cibber. The Lives of the Poets of Great Britain and Ireland, to the Time of Dean Swift. 5 vols. London: R. Griffiths, 1753.

Smith, John, ed. The Life, Journals, and Correspondence of Samuel Pepys. 2 vols. London: R. Bentley, 1841.

Smith, John, and Richard Braybrooke, eds. Diary and Correspondence of Samuel Pepys. 5th ed. 4 vols. London: Henry Colburn, 1854.

Stone, George Winchester, Jr., and George M. Kahrl. David Garrick: A Critical Biography. Carbondale: Southern Illinois UP, 1979.

Theobald, Lewis, ed. The Works of Shakespeare. 7 vols. London: A. Bettesworth etc., 1733.

Vertue, George. "Vertue Note Books." Annual Volume of the Walpole Society 18, 1929-30 (vol. 1); 20, 1931-32 (vol. 2); 22, 1933-34 (vol. 3); 24, 1935-36 (vol. 4); 26, 1937-38 (vol. 5); 29, 1940-42 (index to vols. 1-5); 30, 1951-52 (vol. 6).

Walpole, Horace. Anecdotes of Painting in England; With Some Account of the Principal Artists; and Incidental Notes on Other Arts; Collected by the Late Mr. George Vertue. 2nd ed. 4 vols. Twickenham: Strawberry Hill, 1765-1780.

Watkin-Jones, Alun. "Langbaine's Account of the English Dramatick Poets (1691)." Essays and Studies 21 (1936): 75-85.

Yeowell, James. A Literary Antiquary: Memoir of William Oldys, Esq. London: author, 1862. 


\title{
SHAKESPEARE, CARDENIO IN VERTUEJEVI ROKOPISI
}

\author{
Ključne besede: zgodnjemoderna angleška drama, dvorne predstave, \\ William Shakespeare, Cardenio, Richard Rawlinson, \\ George Vertue, William Oldys, George Steevens, Ed- \\ mond Malone, Gerard Langbaine, opombe, margina- \\ lia, urejanje, zgodovina raziskovanja
}

\section{Povzetek}

Prispevek sledi zgodovini izpiskov Georgea Vertueja iz poročil finančnega ministra, ki so danes del rokopisne zbirke (MS. Rawl. A.) v knjižnici Bodleian. Odlomki, ki se nanašajo na izvedbe iger na dvoru Jamesa I. in so bili izpisani leta 1749 , ko je Rawlinson pridobil relevantne rokopise, so dosegli Wiliama Oldysa in, verjetno kasneje, Davida Garricka. Prek Georgea Steevensa, ki je izpiske dobil od Garricka in jih k sreči v celoti prepisal v svoj komentiran izvod Langbainovega Pregleda angleških dramatikov iz leta 1691 (British Library MSS Add. 22592-22595), je informacija, ki jo odlomki vsebujejo, vstopila v shakespearijanski variorum osemnajstega stoletja. Nejasna, vendar pogosta sklicevanja na zapiske gospoda Vertueja so povzročila veliko zmede med tistimi, ki jih niso imeli, a so morali vendarle upoštevati zgodovinska dejstva, ki so bila občasno citirana iz teh odlomkov. Ob primeru Cardenia, igre, ki je omenjena v finančnih poročilih za leto 1612-13, lahko preučujemo, kako so bili Vertuejevi odlomki - fascinanten primer rokopisne kulture znotraj tiskane knjige - uporabljeni v osemnajstem stoletju in kasneje. 